\title{
Urinary mercury excretion and proteinuria in pathology laboratory staff
}

\author{
W. K. STEWART, H. A. GUIRGiS, J. SANDERSON, AND W. TAYLOR \\ University Department of Community and Occupational Medicine, Ninewells Medical School, \\ University of Dundee, Dundee, Scotland
}

ABSTRACT The use of mercuric chloride as an histological fixative was associated with high environmental atmospheric concentrations of mercury vapour (up to $0.5 \mathrm{nmol} / \mathrm{l}$ ) as well as mercury compounds (total $\mathrm{Hg}$ up to $1.0 \mathrm{nmol} / \mathrm{l}$ ). Technicians exposed to this environment showed increased urinary mercury (median value $265 \mathrm{nmol} / 24 \mathrm{~h}$ ) and protein outputs (median value $117 \mathrm{mg}$ protein/24h). Routine control measures, ventilation and careful handling of mercuric chloride solutions, reduced the level of atmospheric mercury vapour levels to within acceptable limits (threshold limit values $0.01 \mathrm{mg} / \mathrm{m}^{3}(0.05 \mathrm{nmol} / \mathrm{l})$ alkyl compounds and $0.05 \mathrm{mg} / \mathrm{m}^{3}(0.25 \mathrm{nmol} / \mathrm{l})$ for all forms except alkyl). This reduction was associated with the disappearance of trace proteinuria from the technicians' urine. Contamination of histology laboratories by mercuric chloride should be minimised.

Corrosive sublimate $\left(\mathrm{HgCl}_{2}\right)$ was one of the first reagents to be used as a tissue preservative and fixative in histology (Blanchard, 1847). Braus (1896) appears to have been the first to use a mixture of formaldehyde and mercuric chloride. This mixture, generally known as formol-corrosive solution, was advocated as a routine fixative by Carleton (1926) and by Lendrum (1941). Its use is now promoted by the Association of Clinical Pathologists (1966). Other fixatives containing mercuric chloride, such as Zenker's, Susa's and Helly's solutions, are also in common use.

Since 1947 histopathologists in Dundee have routinely used formol-corrosive solution $\left(30 \mathrm{~g} \mathrm{HgCl}_{2}\right.$ in $100 \mathrm{ml}$ commercial formalin diluted with water to 1 litre) for fixing surgical material. The routine procedure for post-mortem material, however, includes preliminary fixation in $10 \%$ formol-saline followed by prolonged immersion (secondary fixation) in $5 \%$ mercuric chloride (saturated corrosive).

This investigation was undertaken to assess whether or not there was mercury absorption in the laboratory staff.

\section{Methods}

POPULATION

Individuals were allocated to one or other of two

Received for publication 13 July 1973

Accepted for publication 8 September 1975 groups depending on whether or not their laboratory used mercurial fixatives.

\section{Group 1 (exposed)}

The laboratory staff of three hospitals used formolcorrosive solution as a routine fixative. The staff consisted of 21 persons: 13 men and eight women, and they all handled, or worked for five to six days each week in a room where formol-corrosive solution was present. Their ages ranged from 17 to 50 years and their period of service in these laboratories varied from seven months to 20 years.

\section{Group 2 (non-exposed)}

The control group consisted of 21 histopathology laboratory workers from another hospital who were using only formalin for routine fixation. They did not use mercury or its compounds for any work, and were selected to match the first group for sex and by decade for age.

\section{ENVIRONMENTAL ASSESSMENT}

The room atmosphere of four laboratories within one hospital pathology department which traditionally uses mercuric chloride fixatives was investigated. These laboratories were:

\section{Histology laboratory $A$}

Mercuric chloride-containing solutions and corrosive-fixed tissue in specimen jars were constantly present; specimen cutting and fixation had always been undertaken in this room. No food or beverage 
was taken in this crowded working space, which had no form of controlled ventilation system.

\section{Histology laboratory $B$}

This was used for microscopy; no mercury compounds were stored and corrosive-fixed tissues were rarely present.

(a) Haematology laboratory $H$

No mercury was used.

(b) Haematology annex $H x$

This was adjacent to haematology laboratory $\mathrm{H}$ and had previously been used for manometric analysis and mercury cleaning. Liquid mercury was found in floor cracks and under parquet floor-blocks.

\section{PLAN OF INVESTIGATION}

During the initial phase, 24-hour urine collections were made from members of staff and measurements taken of mercury in air in histology laboratories (A and B) and in the haematology laboratories ( $\mathrm{H}$ and $\mathrm{Hx}$ ). Control measures were subsequently introduced in histology laboratory A. These consisted of:

1. Educating the staff about the potential hazard.

2. Using surgical gloves for handling fixed tissue specimens.

3. Improving exhaust ventilation with a minimum of 3.5 air changes an hour.

Twelve months after these control measures had been implemented in histology laboratory A, measurements of mercury in air were again taken in laboratories $\mathrm{A}, \mathrm{B}, \mathrm{H}$, and $\mathrm{Hx}$, and 24-hour collections of urine were obtained from nine members of staff then working in histology laboratory A.

\section{Mercury in laboratory air}

The total mercury present in the laboratory atmosphere was estimated by the method of Hanson $e t$ al. (1965). Atmospheric mercury vapour was measured by an ultraviolet absorption method using a Beckman model K 24 meter.

\section{Urine collections}

Each subject provided a 24-hour urine specimen in heavy-metal-free polythene bottles. Five $\mathrm{ml}$ of concentrated hydrochloric acid were added to each bottle as a preservative and samples were stored at a temperature of $4^{\circ} \mathrm{C}$.

Urinary estimation of mercury

A dithizone colorimetric method was used, modified from that of Kudsk (1964).

\section{Urinary protein}

The method was developed from those of Henry et al. (1957) and Kibrick (1958). The proteins were precipitated from a $20 \mathrm{ml}$ aliquot of urine by addition of $5.0 \mathrm{ml}$ of $25 \%$ trichloroacetic acid solution before spectrophotometric estimation using biuret reagent. A standard curve was made using crystallised bovine albumin.

\section{Urinary creatinine}

The alkaline picrate method of Bonsnes and Taussky (1945) was used. Creatinine output was calculated to check that a full 24-hour specimen had been received. All samples were found to be satisfactory by this rough check.

\section{Statistics}

Since the distribution of urinary output rates were not gaussian the significance of differences between the exposed and non-exposed groups in respect of mercury and protein output rates were calculated using the $U$ test (Mann and Whitney, 1947).

\section{Results}

Levels of environmental mercury are given in Table 1. Measurements of total atmospheric mercury in histology laboratory A were up to five times higher than those in haematology laboratory $H$. Raised mercury vapour values, including some of $0.5 \mathrm{nmol} / \mathrm{l}$, were detected in air sampled near the two sinks in histology laboratory $\mathrm{A}$. One of these sinks is customarily used for block-taking, involving the handling of mercuric chloride-fixed specimens and it is conveniently near the ready-use supplies of fixative solution. Disused fixed-specimen storage jars are cleaned out with hot water in the second sink.

Histology laboratory B, selected as another control for laboratory A, gave zero readings for mercury vapour. The finding of traces of mercury vapour and $0 \cdot 20 \mathrm{nmol} / \mathrm{l}$ of total mercury in laboratory $\mathrm{H}$ was unexpected in a control environment. Higher readings in the adjoining annex $\mathrm{Hx}$ also intended as a control led to the discovery of the source, mercury globules in gaps between and under the parquet floor-blocks.

The median urinary mercury excretion among 21 non-exposed technicians was $72 \mathrm{nmol} / 24 \mathrm{~h}$, range 0 to 157 (Fig. 1). By contrast, the median mercury excretion rate was $265 \mathrm{nmol} / 24 \mathrm{~h}$, range 119 to 442 , in 21 similarly employed technicians who were exposed to mercury-containing fixatives. Thus the mercury excretion rate in the mercury-exposed personnel is four times greater than that in the control subjects. The difference is significant $(\mathrm{P}<$ 0.001 ). Similarly the amount of proteinuria in the mercury-exposed individuals as a group is at least twice that in the controls, using as an index either the output rate of protein expressed per 24 hours 
Table 1. Atmospheric mercury levels in the laboratories

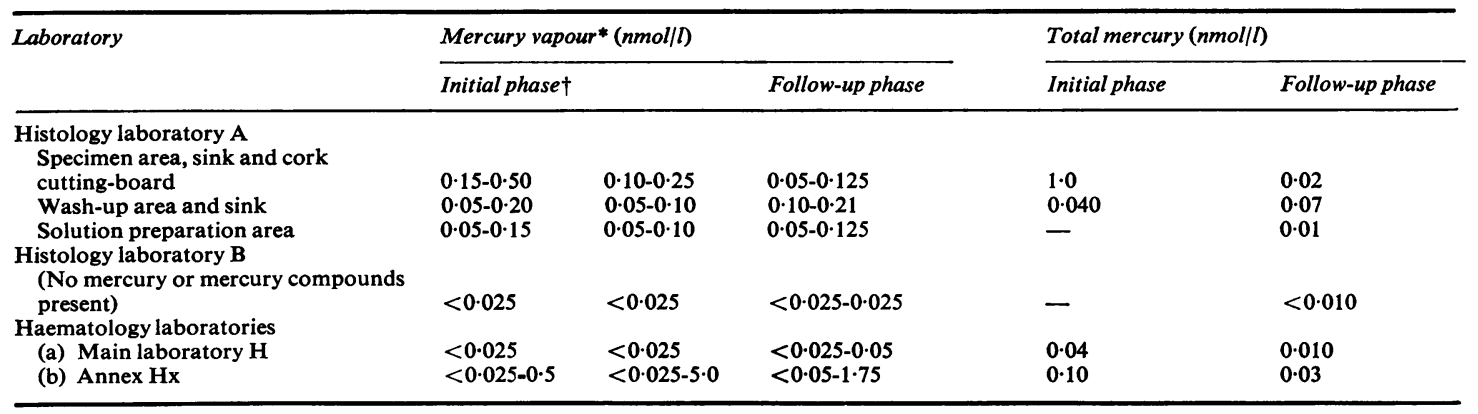

* Range of repeated meter readings

†And on different week-days

Mercury vapour meter detection limit was $0.005 \mathrm{mgHg} / \mathrm{m}^{3}(0.025 \mathrm{nmol} / \mathrm{l})$

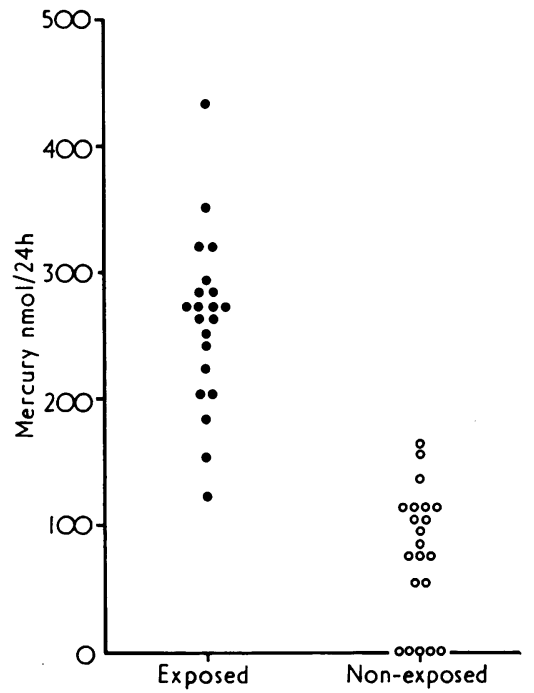

Fig. 1 Urinary mercury excretion rates in mercuryexposed and non-exposed technicians.

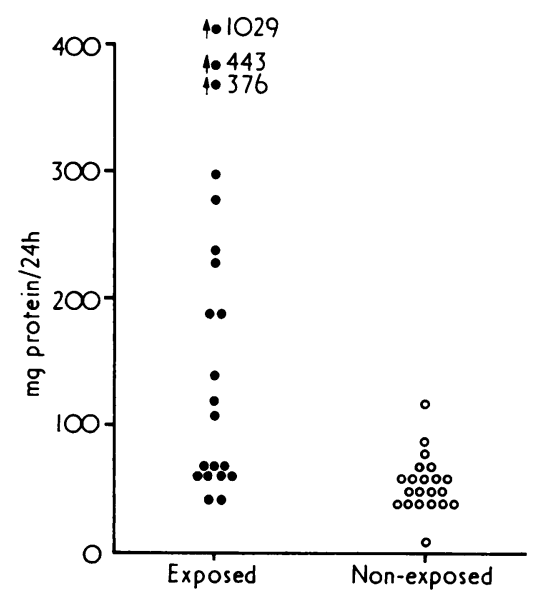

Fig. 2 Urinary protein excretion rates in mercuryexposed and non-exposed technicians.

Table 2. Urinary mercury and protein in exposed and non-exposed technicians

\begin{tabular}{|c|c|c|c|c|c|c|c|}
\hline \multirow[t]{3}{*}{ Phase } & \multirow[t]{3}{*}{ Population } & \multirow{2}{*}{\multicolumn{2}{|c|}{$\frac{\text { Mercury output }}{\text { nmol/24h }}$}} & \multicolumn{4}{|c|}{ Protein output } \\
\hline & & & & \multicolumn{2}{|l|}{$m g / 24 h$} & \multicolumn{2}{|c|}{ mg protein/nmol creatinine } \\
\hline & & Range & Median & Range & Median & Range & Median \\
\hline \multirow[t]{2}{*}{ Initial } & $\begin{array}{l}\text { Group 1 } \\
\quad \text { (exposed) } \\
21 \text { subjects }\end{array}$ & $119-443$ & 266 & $35-1029$ & 117 & $2 \cdot 7-576$ & 115 \\
\hline & $\begin{array}{l}\text { Group 2 } \\
\text { (non-exposed) } \\
21 \text { subjects }\end{array}$ & $0-157$ & 72 & $12-119$ & 48 & $1 \cdot 9-17 \cdot 3$ & $3 \cdot 8$ \\
\hline Follow-up* & $\begin{array}{l}\text { Group 1 } \\
\text { (exposed) } \\
9 \text { subjects }\end{array}$ & $0-70$ & 40 & $16-59$ & 35 & $1 \cdot 8-7 \cdot 5$ & $4 \cdot 0$ \\
\hline
\end{tabular}

*12 months after control measures were implemented 
(Fig. 2), or, an indirect measure in which urinary protein is expressed per gram of accompanying creatinine output. The difference in the amount of proteinuria shown by the exposed and non-exposed groups is also significant $(\mathbf{P}<0.01)$. These results are summarised in Table 2.

In the follow-up phase, mercury vapour levels were not changed materially in either of the histology laboratories but total mercury levels in histology laboratory A were lower (Table 1). Urinary mercury and protein outputs of technicians working with formol-corrosive fixative, but using control measures (Table 2), were comparable with those of nonexposed technicians (Group 2).

An attempt was made to remove metallic mercury found in the floor of the haematology annex (Hx), and then the parquet-blocks were covered with linoleum. Spillages were first cleared up by mechanical means, that is by vacuum probe, and the affected areas were then treated with a wash composed of equal parts of slaked lime and flowers of sulphur mixed with water to form a paste. Twentyfour hours later the wash was removed with clean water and the surfaces allowed to dry.

\section{Discussion}

ENVIRONMENTAL MERCURY

The demonstration of significant amounts of mercury in the atmosphere of one representative laboratory (A), in which technicians used mercuric fixatives, raises the question of a potential mercury hazard. The presence of mercury in the haematology annex was unexpected and was found to be a legacy from an earlier use of this room for mercury cleaning and manometric analysis. Other control work-spaces gave negligible values for mercury.

There were several sources of contamination including bench spillage of corrosive sublimate solution, floor spillage (in this case on to wooden parquet-blocks), saturated filter papers lying exposed in the laboratory atmosphere, as well as the possibility of contamination of clothing worn by laboratory staff. Local transient high concentrations of mercury vapour were obtained by warming the copper handles of test-tube brushes found in sink areas. When hot water was allowed to run through the sinks to waste, consistent mercury vapour values above $0.5 \mathrm{nmol} / 1$ were obtained.

The threshold limit value for non-alkyl mercury absorbed through the skin has been reduced to $0.25 \mathrm{nmol} / 1$ from $0.5 \mathrm{nmol} / 1$ and for alkyl compounds to $0.05 \mathrm{nmol} / 1$ (American Conference of Governmental Industrial Hygienists, 1975; Department of Employment, 1973).

It is noteworthy that mercuric chloride has a vapour pressure of the same order as that of metallic mercury. The values are $3 \cdot 1 \times 10^{-4}$ torr $^{1}$ for $\mathrm{HgCl}_{2}$ and $18 \times 10^{-4}$ torr for $\mathrm{Hg}$ at $25^{\circ} \mathrm{C}$ and under one atmosphere (extrapolated from data of Johnson, 1911). The maximum concentration of mercuric chloride in air would occur only in a closed space and lesser values would bc found in open laboratories depending on air movement, temperature, and proximity to the mercury source. Formaldehyde which is commonly associated with mercuric chloride in fixatives can partly reduce mercuric to mercurous chloride. Reduction to free mercury has not been found. Solid mercuric chloride sublimes at room temperature and a likely source of mercury atmosphere contamination in the histology laboratory is evaporation of spilled solutions.

Several common metals interact with mercuric chloride releasing mercury or forming amalgams. These metals include copper, zinc, lead, and aluminium which are likely to be present as part of the plumbing, sinks, and the related metal fittings of histology laboratories. This effect may in part account for the higher concentrations of mercury found in air near the sinks in this investigation.

URINARY MERCURY EXCRETION

The technicians forming the non-exposed group showed a range of mercury excretion rates in urine which is similar to the normal range for the method used: 0 to $141 \mathrm{nmol} / 24 \mathrm{~h}$, median value 52 in 33 normal subjects (Taylor et al., 1969). The detection limit for this method is $20 \mathrm{nmol} / \mathrm{l}$. Earlier authors quote comparable normal mercury values: 0 to 150 nmol/l (Nobel and Nobel, 1958; Kudsk, 1964) and less than 100 to $125 \mathrm{nmol} / \mathrm{l}$ (Goldwater, 1964).

Technicians who were exposed to mercury compounds had as a group appreciably higher urinary mercury output than the paired control subjects or other normal subjects. In 19 of 21 exposed subjects the output of mercury exceeded $150 \mathrm{nmol} / \mathrm{l}$ with fairly wide variability. Large day-to-day variability in and between exposed individuals in the output of mercury has been noted before (Buckell et al., 1946; Goldwater, 1964).

\section{URINARY PROTEIN EXCRETION}

As a group the exposed workers had an increased rate of excretion of protein in the urine compared with the group of matched controls who were all within the expected upper limit of adult normality for the method (Taylor et al., 1969). Although method dependent (Jorgensen, 1967), the upper limit of normal urinary protein excretion is between 100 and $150 \mathrm{mg} / 24 \mathrm{~h}$, mean value between 40 and $80 \mathrm{mg} / 24 \mathrm{~h}$ (Relman and Levinsky, 1971). Paraproteinuria (globulins rather than albumin) in 11 torr $\approx 1 \mathrm{mmHg} \approx 133 \mathrm{~N} / \mathrm{m}^{2}$ 
particular is not readily detected by Albustix-reagent strips (Rennie and Keen, 1967) but can be measured colorimetrically.

In nine of the 21 technicians in Group 1 the daily protein output rate exceeded $180 \mathrm{mg}$. This finding, accompanying a raised level of mercury excretion suggests that the repeated handling and/or inhalation of mercury and its bichloride salt, may cause an increase in the rate of protein excretion. There was a large variation in the protein excretion rate within the exposed group and a poor correlation between mercury and protein output rates for individual subjects, which suggest that a simple dose and effect relationship does not apply. This variability may well reflect differences in the extent of exposure from day to day, as well as underlying differences between technicians in their susceptibility to the effects of mercury once absorbed. No attempt was made to measure the duration of exposure time in technicians.

Overt clinical evidence of mercury poisoning was not found in the pathology technicians during the course of this study. The clinical significance of the minimal proteinuria found in the histopathology laboratory staff is not known. Comparative quantitative studies of trace proteinuria present in other populations exposed to industrial processes with environmental mercury concentrations at or above the threshold limit values would be valuable. In industrial situations proteinuria and urinary mercury excretion values (West and Lim, 1968) greater by a factor of 10 than those found in this study are currently accepted and are assumed to carry minimal health risk. The possibility remains however that trace proteinuria is a manifestation of mercury toxicity, albeit minimal. The occurrence of heavy proteinuria (more than $2 \mathrm{~g} / 24 \mathrm{~h}$ ) would warrant the removal of the subject from exposure to mercury and its compounds. In the case of the trace proteinuria associated with minimally increased urinary excretion of mercury as found here accompanying routine histopathological work, the long-term clinical significance is unknown.

MERCURY ABSORPTION CONTROL MEASURES Mercury vapour from manometric apparatus is a recognised risk in hospital laboratories (Williams et al., 1968). The current data indicate that the mercuric chloride used in histology also represents a potential hazard. To reduce contamination of skin and absorption by inhalation, laboratory staff should avoid spillage, work benches and floors should have impermeable surfaces without open joints, efficient ventilation should be provided, and the wearing of impermeable gloves is advisable. Simple control measures applied in histology labora- tory A were effective in reducing the total atmospheric mercury to acceptable levels. Concurrently with this environmental change the urinary output rates of mercury and of protein also returned to the normal range.

The fortuitous observation of high levels of total mercury and mercury vapour concentration in the haematology annex led to the discovery of longstanding contamination of that room by metallicmercury. This finding, together with the accompaniments of the use of formol-corrosive tissue fixative already described, re-emphasizes that mercury and its compounds are an occupational hazard of laboratory technicians (Rose et al., 1972; Lancet, 1975).

The use of mercury-containing fixatives calls for special precautions. Not the least of these is the safe, pollution-avoiding disposal of the waste fixative as recommended by Porter (1972).

We wish to thank Professor A. Mair (University Department of Community and Occupational Medicine), Professor A. C. Lendrum (University Department of Pathology), the Medical School, Ninewells, Dundee; Professor A. Currie (Aberdeen); Dr George H. Smith (Maryfield Hospital, Dundee); Dr J. H. Prain (Perth Royal Infirmary, Perth), and the staff of the Pathology Departments concerned whose willing co-operation made this investigation possible. A generous grant from the Advisory Committee for Medical Research (ACMR) to W. K. Stewart and W. Taylor, is gratefully acknowledged.

\section{References}

American Conference of Governmental Industrial Hygienists (1975). Documentation of the Threshold Limit Values for Substances in Workroom Air, 4th edition, pp. 150-151. ACGIH: Cincinnati.

Association of Clinical Pathologists (1966). Histological fixation of human tissues. Broadsheet No. 51 .

Blanchard, E. (1847). Recherches sur l'organisation des vers. Annales des Sciences Naturelles, (Zool.), 8, 271-341.

Bonsnes, R. W., and Taussky, H. H. (1945). The colorimetric determination of creatinine by the Jaffe reaction. Journal of Biological Chemistry, 158, 581-591.

Braus, H. (1896). Untersuchungen zur vergleichenden Histologia der Leber der Wirbelthiere. Denkschriften der Medizinisch-naturwissenschaftlichen Gesellschaft zu Jena, 5, 301-367. Quoted by G. Mann (1902) in Physiological Histology, p. 100. Clarendon Press: Oxford.

Buckell, M., Hunter, D., Milton, R., and Perry, K. M. A. (1946). Chronic mercury poisoning. British Journal of Industrial Medicine, 3, 55-63.

Carleton, H. M. (1926). Histological Technique, p. 37. University Press: Oxford.

Department of Employment (1973). Technical Data Note 21 (REV), Mercury. HM Factory Inspectorate. HMSO: London. 
Goldwater, L. J. (1964). Occupational exposure to mercury. In the Harben Lectures. Journal of the Royal Institute of Public Health and Hygiene, 27, 279-301.

Hanson, N. W., Reilly, D. A., and Stagg, H. E. (Editors) (1965). The Determination of Toxic Substances in Air, pp. 162-164. Heffer: Cambridge.

Henry, R. J., Sobel, C., and Berkman, S. (1957). Interferences with biuret methods for serum proteins. Use of Benedict's qualitative glucose reagent as a biuret reagent. Analytical Chemistry, 29, 1491-1495.

Johnson, F. M. G. (1911). The vapour pressure of mercuric chloride, bromide and iodide. Journal of the American Chemical Society, 33, 778-781.

Jorgensen, M. B. (1967). A gel filtration method for the determination of protein in normal urine. Acta Medica Scandinavica, 181, 153-162.

Kibrick, A. C. (1958). Extended use of Kingsley biuret reagent. Clinical Chemistry, 4, 232-236.

Kudsk, F. N. (1964). Determination of mercury in biological materials. A specific and sensitive dithizone method. Scandinavian Journal of Clinical and Laboratory Investigation, 16, 575-583.

Lancet (1975). Editorial. Mercury spillage. Lancet, 1, 1021.

Lendrum, A. C. (1941). On the fixation of post-mortem material. Journal of Pathology and Bacteriology, 52, 132-137.
Mann, H. B., and Whitney, D. R. (1947). On a test of whether one or two random variables is stochastically larger than the other. Annals of Mathematical Statistics, 18, 50-60.

Nobel, S., and Nobel, D. (1958). Determination of mercury in urine. Clinical Chemistry, 4, 150-158.

Porter, D. D. (1972). Editorial. Mercury pollution by tissue fixatives. Archives of Pathology, 94, 279.

Relman, A. S., and Levinsky, N. G. (1971). In Diseases of the Kidney. Edited by M. G. Strauss and L. G. Welt, Vol. 1, p. 89. Little, Brown: Boston.

Rennie, I. D. B., and Keen, H. (1967). Evaluation of clinical methods for detecting proteinuria. Lancet, 2, 489-492.

Rose, K. D., Simpson, E. W., Jr., and Weed, D. (1972). Contamination by mercury in chemical laboratories. Journal of the American College Health Association, 20, 197-199.

Taylor, W., Guirgis, H., and Stewart, W. K. (1969). Investigation of a population exposed to organomercurial seed dressings. Archives of Environmental Health, 19, 505-509.

West, I., and Lim, J. (1968). Mercury poisoning among workers in California's mercury mills. Journal of Occupational Medicine, 10, 697-701.

Williams, H. L., Majer, A. J., Custer, J. L., and Miller, F. C. (1968). A survey of mercury vapour hazards in hospital. American Industrial Hygiene Association Journal, 29, 186-188. 